\title{
複合環境評価実験における非特異的尺度の「寒暑の印象」と 「涼暖の印象」の比較 \\ COMPARISON BETWEEN THE IMPRESSION OF HOT-COLD AND WARM-COOL IN UNSPECIFIC SCALE ON THE EVALUATION OF THE EXPERIMENTAL COMBINED ENVIRONMENT
}

松原斎樹*1, 島田理良*2, 藏澄美仁*3, 合掌 顕*4, 飛田国人*5

\section{Naoki MATSUBARA, Riryo SHIMADA, Yoshihito KURAZUMI,} Akira GASSHO and Kunihito TOBITA

\begin{abstract}
Several analysis were applied to the experimental data obtained from the different environmental conditions and procedures to investigate the difference between two unspecific scales; the impression of "hot-cold" and "warm-cool".

The main results are as follows; 1) "warm-cool" was different from "hot-cold" in the degree of the influence of temperature and the auditory factor, 2) the possibility was shown that "warm-cool" and "hot-cold" were not on the one-dimensional placement, 3) the difference of the degree of the influence of the auditory factor was conspicuously shown by combining with temperature.
\end{abstract}

Keywords: Combined environment, unspecific scale, temperature, auditory factor, one-dimensional placement 複合環境，非特異的尺度，温熱要因，聴覚要因，一次元配置

\section{1. 背景及び目的}

筆者らは一連の複合環境評価研究 1) -9) の中で，評価尺度に使用 する尺度は，特定の要因に限定される特異的尺度ではなく異種の要 因に共通する非特異的尺度がふさわしいことを論じてきた ${ }^{10)}$, 11)。 また，非特異的尺度に関する理論的考察も行ってきた。

非特異的尺度が有効である理由は，複合環境評価の研究の多くは 温熱環境条件と温熱感覚の関係に対して，色彩などの副次的要因が 与える影響 ${ }^{12-18)}$, 景観の印象に及ぼす音環境の影響や音環境の印象 に及ぼす景観の影響 ${ }^{19)}$ ，気温が色温度の好ましさに及ぼす影響 20 等の解明を主目的としていたのに対して，筆者らは異種要因を等価 なものとして扱うことを意図していたためである。換言すると，そ れらの複合的・総合的な影響を明らかにするためには非特異的尺度 を用いて測定することがふさわしいということである。

「非特異的(non-specific or unspecific)」という用語は生命科学・医 学分野等では学術用語として定着しており 21)-23), 今後，建築分野 でも非特異的尺度の理解を深めていくことは有意義である。
このことは古くは, セリエのストレス学説における適応症候群 ${ }^{24)}$ の概念にルーツを見ることが出来よう。

筆者らの一連の複合環境評価に関する研究は，熱・音・光等に特 異的な尺度ではなく, 非特異的尺度を使用することが特徵である。 従って, 熱に特異的な尺度（例えば ASHRAE の 7 段階温冷感尺度, 温熱的快適感）に対して, 空間の印象としての「涼暖の印象」「寒暑 の印象」等を非特異的尺度として扱ってきた。初期の研究では，特 異的尺度を用いることが非特異的尺度の評価にバイアスを与えるこ とを懸念して，非特異的尺度のみを使用してきた。しかし， 2 種類 の尺度の比較を行うことは出来なかった。そこで，その後の研究で は非特異的尺度と特異的尺度を同時に使用している。

筆者らの hue-heat 仮説に関する実験研究 ${ }^{25}$ )では，色彩の温熱的な 影響を解明することを目的としていた。その中で「寒暑の印象」と 「涼暖の印象」の両評価尺度の関係について,『両尺度の室温との相 関が「涼暖の印象」に比べ「寒暑の印象」が若干高く, 温熱要因の 寄与が高い評価となっているように思える』と報告している。また
*1 京都府立大学大学院生命環境科学研究科 教授. 工博

*2 大和八ウス工業(株)

*3 椙山女学園大学生活科学部生活環境デザイン学科 教授. 工博

*4 岐阜大学地域科学部 准教授. 博士 (工学)

*5 有明工業高等専門学校建築学科 助教・博士 (学術)
Prof., Division of Environmental Sciences, Kyoto Pref. Univ., Dr. Eng.

Daiwa House Industry Co., Ltd.

Prof., Dept. of Human Environment Design, School of Life Studies, Sugiyama Jogakuen Univ., Dr. Eng.

Assoc. Prof., Faculty of Regional Studies, Gifu Univ., Dr. Eng.

Assist. Prof., Dept. of Architecture, Ariake National College of Technology, Ph. D. 
同報にて,「寒暑の印象」は「涼暖の印象」に比べ色彩（温熱環境要 因以外の環境要因）の影響が少なく，その理由として「寒暑」とい う感覚が，「涼暖」という感覚と一次元上に配置されていることを示 唆しているが，一方で両評価尺度と室温との相関が異なる点が多々 見られ，一次元上に並ばない可能性もあると報告している。

他の先行研究では, Kuno et.a $\left.\right|^{26)}$, 堀越ら ${ }^{27)}$, 大野ら ${ }^{28)}$, 兼子ら ${ }^{29)}$ が温熱環境に特異的な評価尺度としての「寒い- 暑い」「涼しい- 䁔 かい」の感覚は，一次元上に配置されないと述べている。しかし， 非特異的評価尺度としての「寒暑の印象」と「涼暖の印象」の比較 に関するデータ分析及び考察は, (先の実験研究 ${ }^{25}$ )では温度条件が 2 段階の散布図上考察であった）ほとんどない。従って，この比較は 新たな知見をもたらすものであると言える。

松原ら 30） は「温冷感」「涼暖の印象」「寒暑の印象」の 3 つの尺 度と室温と関係に注目し, 温熱・視覚・聴覚要因の複合環境評価実 験のデータに対して, 説明変数を室温, 目的変数を評価尺度とした 線形回帰分析を行った。その結果，視覚要因あるいは聴覚要因の提 示，または視覚要因・聴覚要因を同時に提示寸ると，提示のない場 合と比較して, 回帰式の勾配が小さいことを明らかにした。島田ら 31) は, 「寒暑の印象」は「温冷感」よりも回帰勾配が小さく, 回帰切片 項にも差があることを示し，このことから特異的尺度の「温冷感」 は温熱要因に対する反応がより大きく, 非特異的尺度の「寒暑の印 象」「涼暖の印象」は聴覚要因, 視覚要因に対する反応がより大きい ことを明らかとした。このことは，非特異的尺度では，温熱要因以 外の聴覚要因, 視覚要因にも注意が配分されたために反応に差が現 れ, 一方で温熱要因に対する注意資源が特異的尺度に比べて減少し たことで温熱要因に対する反応が減少したと考えられた。

注意に関する報告は, 後に須藤ら ${ }^{32)}$ があり, 教示によって被験者 の注意を視覚要因, 温熱要因に向ける複合環境評価実験を行い, 注 意を実験要因に含めることによって複合環境評価において注意が重 要な役割を果たすことを実証している。

しかし, 既報 30)，31)では，特異的尺度と非特異的尺度の比較が主 目的であったため「涼暖の印象」と「寒暑の印象」の非特異的尺度比 較は出来ていなかった。先に述べたような『両尺度の室温との相関 が「涼暖の印象」に比べ「寒暑の印象」が若干高く, 温熱要因の寄 与が高い評価となっているように思える』とした報告 ${ }^{25}$ は非特異的 尺度間においても注意の影響が温熱要因の寄与に影響した可能性も ある。

そこで, 本研究では非特異的評価尺度の「涼暖の印象」と「寒暑 の印象」の 2 つの非特異的尺度の比較を行うことを目的とする。具 体的には, 温熱要因(室温) との相関係数を算出し, 既報 ${ }^{25}$ ) との比較 を行い「涼暖」「寒暑」の一次元上配置についての考察を行う。さら に島田ら ${ }^{31)}$ と同様の方法を用いて, 環境要因が与える影響差の比較 を行い，両評価尺度の差異を明らかにする。最後に，これらの差異 を「注意」概念を用いて考察する。「涼暖の印象」と「寒暑の印象」の 違いを明らかにすることは, より適切な尺度を選択する場合に, 有 意義であり，建築環境の向上に役立つものと考えられる。

\section{2. 方法}

\section{1 実験概要}

本研究では既報 30),31) で使用した複合環境実験データを再分析す
る。各実験データの実験室環境条件は基準状態(表 1) と呼ぶ環境条件 に聴覚要因, 視覚要因及び聴覚十視覚要因の環境要因提示を行った 環境条件がある。基準状態では, 各実験データで暴露する環境要因 は主に温熱要因である室温・湿度・着衣量・気流, 視覚要因である 照度・スライド・カーテン, 聴覚要因である暗騒音がある。実験 $\mathrm{A}$ では，室温： $26.0,29.0,32.0,34.0^{\circ} \mathrm{C}$, 照度 : $5 \mathrm{~lx}$ ，暗騒音 Leq $45.2 \mathrm{~dB}(\mathrm{~A})$ である。実験 B では, 室温: 21.0, 22.5, 24.0, 25.5, 27.0 ${ }^{\circ} \mathrm{C}$ ， 照度 $1000 \mathrm{~lx}$, 暗騒音 Leq $43.8 \mathrm{~dB}(\mathrm{~A})$ である。実験 C では, 室温 : $27.0,28.5,30.0,31.5,33.0^{\circ} \mathrm{C}$ であり, 照度及び暗騷音は実験 B と同 值である。また全ての実験において湿度・気流・着衣量は同值であ り，それぞれ $50 \%, 0.2 \mathrm{~m} / \mathrm{s}$ 以下, 0.4 clo である。

表 1 基準状態

\begin{tabular}{|c|c|c|c|}
\hline データ記号 & A & B & $\mathrm{C}$ \\
\hline 出典 & 文献33 & 文献34 & 文献35 \\
\hline 実験室温条件 $\left({ }^{\circ} \mathrm{C}\right)$ & $\begin{array}{ll}26.0, & 29.0 \\
32.0, & 34.0\end{array}$ & $\left|\begin{array}{c}21.0,22.5,24.0 \\
25.5,27.0\end{array}\right|$ & $\begin{array}{l}27.0,28.5,30.0 \\
\quad 31.5,33.0\end{array}$ \\
\hline 暗騒音 (dB) & 45.2 & \multicolumn{2}{|c|}{43.8} \\
\hline 照度 ( L x ) & 5 & \multicolumn{2}{|c|}{1000} \\
\hline 視覚要因 & $\begin{array}{l}\text { スライド } \\
\text { 画像なし }\end{array}$ & $\begin{array}{r}\text { カー } \\
\text { 暖色 }(2.5 \mathrm{YR} 6 / 16\end{array}$ & $\begin{array}{l}\text { テン } \\
\text { 5) 寒色 (5B6/8) }\end{array}$ \\
\hline
\end{tabular}

*全実験計画において湿度 $50 \%$, 気流 $0.2 \mathrm{~m} /$ 以下, 着衣量 $0.4 \mathrm{clo}$

\section{1.1 各実験の手続き}

実験 $\mathrm{A}$ では，実験室に入室し，30 分間の温度順応及び暗順応の 時間を取り, 30 分経過後に実験を開始し 65 分 40 秒後に終了寸る。

「呈示します」という声の後, 何も呈示しない基準状態, 視覚要因 呈示, 聴覚要因呈示, 視覚と聴覚要因呈示の順に呈示し, 刺激呈示 後 10 秒間は評定せずに呈示刺激に注目しその後 60 秒間に評定を行 う。評定の間も聴覚要因または視覚要因は呈示されており自由に見 聞きすることができる。これらを 1 セットとし， 3 セット 12 回の評 定を終えた後, 3 分間休款し, その後 4 セット 16 回の評定を終え 1 回の実験を終了する。被験者は温熱要因(室温)条件(26.0, 29.0, 32.0, $\left.34.0^{\circ} \mathrm{C}\right)$ の全てと全ての呈示刺激条件を経験するが, 呈示順序はラン ダム表により決定した。

実験 B,C では，まず前室(実験 B・15 分，実験 $\mathrm{C} ・ 30$ 分)で温度 順応時間を取り，その後実験室に入室し 30 分間の温度順応時間を 取る。入室直後から 10 分間で 5 回の視覚要因呈示(暖色・寒色の壁 面 4 面に覆われたカーテン)の基準状態に関寸る評価を行い, 40 分 経過後に聴覚実験を開始する。始めに 60 秒間で暗騒音についての 評価を行い, 続けて聴覚要因の呈示が開始される。呈示順序はラン ダム表により決定し, 始めに 30 秒間, 聴覚刺激に注目してもらい, 30 秒後に 60 秒間で評定を行う。被験者は温熱要因(室温)条件(実験 B : $21.0,22.5,24.0,25.5,27.0^{\circ} \mathrm{C}$, 実験 C : 27.0, 28.5, 30.0, 31.5, $33.0^{\circ} \mathrm{C}$ )の内， 1 つの温度条件と全ての呈示刺激条件を経験する。

\subsection{2 データの抽出}

実験 A では, 聴覚と視覚要因刺激の履歴影響が最も少ないと考え られる「温度順応時間直後」と「途中休䕀後」の申告值を抽出した。 実験 B,C では, 実験室温度に十分暴露されたと考えられる 40 分後 の申告值を抽出し，これを基準状態の申告值とした。 
聴覚要因呈示の環境条件(以後, 聴覚要因呈示状態と呼ぶ) は, 被 験者が暴露される環境要因は, 基準状態にある環境要因と聴覚要 因・環境音である。実験 A では, 「視覚要因呈示状態」及び「視覚・ 聴覚要因呈示状態」があるが, 実験 B,C にはこれらの呈示刺激はな い。本研究では各実験データの共通事象を示すことが主目的である ため, 分析対象から外した。聴覚要因呈示の種類を表 2 に示す。こ れら聴覚要因は実験 $\mathrm{A}$ と実験 $\mathrm{B}, \mathrm{C}$ で異なる効果音 $\mathrm{CD}$ から抜粋した

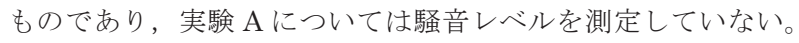

これら二つの実験室環境条件「基準状態」「聴覚要因呈示状態」か ら非特異的尺度の関係を分析する。非特異的尺度「涼暖の印象」「寒 暑の印象」の 2 つの評価尺度を図 1-a,1-b に示す。それぞれ両極に 「暖かい」「涼しい」，「暑い」「寒い」を配置しており，既報 30)，31） 及び本研究において, 間隔尺度として処理した。なお，各実験デー タでは「温冷感」も同時に使用しているが，本研究の目的外のため これらの結果提示を控えている。「温冷感」についての結果は既報 30)，31）を参照されたい。「寒暑の印象」「涼暖の印象」の教示は共に 「室内の印象を総合的に評価してください」である。

表 2 聴覚要因呈示(環境音)の種類

\begin{tabular}{|c|c|}
\hline データ記号 & 聴覚要因・環境音 \\
\hline A & $\begin{array}{c}\text { 鳥・蟬・川・滝 } \\
\text { 風鈴・花火・交通騒音 }\end{array}$ \\
\hline B, C & 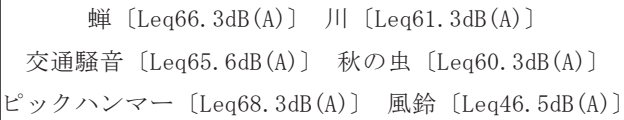 \\
\hline
\end{tabular}

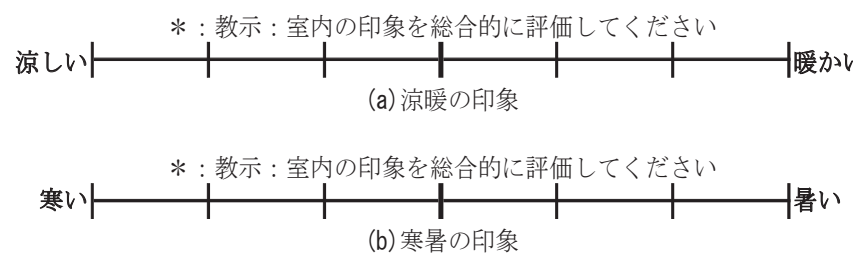

図 1 非特異的尺度の種類

\section{2 統計解析方法}

本研究では温熱要因 (室温) と各評価尺度との関係を把握するため に相関係数の算出及び回帰分析を行う。さらに，2 つの尺度の申告 值を比較するため $\mathrm{t}$ 検定を, また, 聴覚・視覚・温熱要因が両評価 尺度に影響しているかを把握するために，これら環境要因を 3 因子 とした 3 元配置分散分析を行う。また, 聴覚要因呈示状態による申 告值の差が評価尺度間で異なるかを把握するため, 2 元配置分散分 析の交互作用検定で把握する。

\section{3. 結果及び考察}

\section{1 評価尺度と温熱要因（室温）との相関関係}

\subsection{1 基準状態}

基準状態における温熱要因(室温) と評価尺度の相関係数は, 実験 $\mathrm{A}$ の「寒暑の印象」「涼暖の印象」共に $\mathrm{r}=0.63(\mathrm{p}<0.01, \mathrm{~N}=160)$ であつ た。実験 B,C・暖色の「寒暑の印象」は $\mathrm{r}=0.54(\mathrm{p}<0.01, \mathrm{~N}=92)$, 「涼 暖の印象」は $\mathrm{r}=0.50(\mathrm{p}<0.01, \mathrm{~N}=92)$ であった。実験 $\mathrm{B}, \mathrm{C}$ ・寒色の「寒 暑の印象」は $\mathrm{r}=0.55(\mathrm{p}<0.01, \mathrm{~N}=92)$, 涼暖の印象」は $\mathrm{r}=0.52(\mathrm{p}<0.01$,
$\mathrm{N}=92)$ であった。相関係数の差の検定を行ったところ,「寒暑の印象」 と「涼暖の印象」に有意差 $(\mathrm{p}<0.05)$ は示されなかった。

\subsection{2 聴覚要因呈示状態}

聴覚要因呈示状態での温熱要因(室温)と評価尺度の相関係数を表 $3 \sim 5$ に示す。

実験 $\mathrm{A}$ (表 3)より, 相関係数の有意確率は全条件で有意 $(\mathrm{p}<0.01)$ であった。実験 B,C・暖色(表 4)及び寒色(表 5)より，「涼暖の印象」 の「秋の虫」「川」「風鈴」では相関係数の有意確率が有意ではなか ったが，その他の条件では有意であった（ $\mathrm{p}<0.05 ）$ 。「寒暑の印象」 「涼暖の印象」の相関係数の差の検定を行ったところ, 有意差は示 されなかった。

\section{1 .3 基準状態と聴覚要因呈示状態の比較}

基準状態と聴覚要因呈示状態(表 3〜 5)の相関係数を比べると, 聴 覚要因呈示状態の相関係数が低い。相関係数の差の検定を行ったと ころ, 実験 $\mathrm{A}$ (表 3)の「寒暑の印象」では, 基準状態と「蝉」で有意差 $(\mathrm{p}<0.01)$ が示された。「涼暖の印象」では, 基準状態と「交通騒音」, 「蝉」,「鳥」で有意差 $(\mathrm{p}<0.05)$ が示された。実験 $\mathrm{B}, \mathrm{C} ・$ 暖色(表 4)の「寒 暑の印象」では, 基準状態と「蝉」で有意差傾向 $(\mathrm{p}<0.1)$, 「秋の虫」, 「川」で有意差 $(\mathrm{p}<0.05)$ が示された。「涼暖の印象」では, 基準状態と 「蝉」で有意差傾向 $(\mathrm{p}<0.1)$ が示された。実験 B,C・寒色(表 5)の「寒暑 の印象」では, 基準状態と「秋の虫」で有意差傾向 $(\mathrm{p}<0.1)$, 「川」,「風 鈴」で有意差 $(\mathrm{p}<0.05)$ が示された。その他の条件では有意差は示され

表 3 室温との相関関係 (実験 A)

\begin{tabular}{cccc}
\hline 聴覚要因 & 寒暑の印象 & 涼暖の印象 & $\mathrm{N}$ \\
\hline 基準状態 & $0.63(\mathrm{p}<0.01)$ & $0.63(\mathrm{p}<0.01)$ & 160 \\
交通騒音 & $0.44(\mathrm{p}<0.01)$ & $0.38(\mathrm{p}<0.01)$ & 80 \\
花火 & $0.50(\mathrm{p}<0.01)$ & $0.46(\mathrm{p}<0.01)$ & 80 \\
蝉 & $0.33(\mathrm{p}<0.01)$ & $0.41(\mathrm{p}<0.01)$ & 80 \\
滝 & $0.62(\mathrm{p}<0.01)$ & $0.61(\mathrm{p}<0.01)$ & 80 \\
鳥 & $0.53(\mathrm{p}<0.01)$ & $0.42(\mathrm{p}<0.01)$ & 80 \\
川 & $0.57(\mathrm{p}<0.01)$ & $0.54(\mathrm{p}<0.01)$ & 80 \\
風鈴 & $0.47(\mathrm{p}<0.01)$ & $0.52(\mathrm{p}<0.01)$ & 80 \\
\hline
\end{tabular}

表 4 室温との相関関係 (実験 B, C・暖色)

\begin{tabular}{cccc}
\hline 聴覚要因 & 寒暑の印象 & 涼暖の印象 & $\mathrm{N}$ \\
\hline 基準状態 & $0.54(\mathrm{p}<0.01)$ & $0.50(\mathrm{p}<0.01)$ & 92 \\
交通騒音 & $0.44(\mathrm{p}<0.01)$ & $0.40(\mathrm{p}<0.01)$ & 92 \\
ピックハンマー & $0.41(\mathrm{p}<0.01)$ & $0.35(\mathrm{p}<0.01)$ & 92 \\
蝉 & $0.31(\mathrm{p}<0.01)$ & $0.25(\mathrm{p}<0.05)$ & 92 \\
秋の虫 & $0.28(\mathrm{p}<0.01)$ & $0.03(\mathrm{p}>0.1)$ & 92 \\
川 & $0.29(\mathrm{p}<0.01)$ & $0.15(\mathrm{p}>0.1)$ & 92 \\
風鈴 & $0.38(\mathrm{p}<0.01)$ & $0.15(\mathrm{p}>0.1)$ & 92 \\
\hline
\end{tabular}

表 5 室温との相関関係 (実験 B, C・寒色)

\begin{tabular}{cccc}
\hline 聴覚要因 & 寒暑の印象 & 涼暖の印象 & $\mathrm{N}$ \\
\hline 基隻状態 & $0.55(\mathrm{p}<0.01)$ & $0.52(\mathrm{p}<0.01)$ & 92 \\
交通騷音 & $0.45(\mathrm{p}<0.01)$ & $0.36(\mathrm{p}<0.01)$ & 92 \\
ピックハンマー & $0.39(\mathrm{p}<0.01)$ & $0.35(\mathrm{p}<0.01)$ & 92 \\
蝉 & $0.43(\mathrm{p}<0.01)$ & $0.34(\mathrm{p}<0.01)$ & 92 \\
秋の虫 & $0.34(\mathrm{p}<0.01)$ & $0.08(\mathrm{p}>0.1)$ & 92 \\
川 & $0.27(\mathrm{p}<0.01)$ & $0.12(\mathrm{p}>0.1)$ & 92 \\
風鈴 & $0.29(\mathrm{p}<0.01)$ & $0.06(\mathrm{p}>0.1)$ & 92 \\
\hline
\end{tabular}


なかった。

実験 B,C・暖色(表 4)及び寒色(表 5)の「涼暖の印象」は「秋の虫」 「川」風鈴」で相関係数の有意確率が $\mathrm{p}>0.1$ であったため，差の検定 を控えたが，相関係数の有意確率が有意でないことは聴覚要因の影 響と言えよう。

以上の結果から，相関係数の有意確率が有意であった条件では，

「寒暑の印象」と「涼暖の印象」の相関係数に基準状態, 聴覚要因 呈示状態共に有意差が無いことが示された。松原ら 25) は『「涼暖の 印象」に比べ「寒暑の印象」が若干高く, 温熱要因の寄与が高い評 定となっているように思える』と報告しているが，本研究の温熱要 因(室温)之評価尺度の相関係数差の分析においてこれらを証明する 結果は得られなかった。

しかし，「涼暖の印象」で，聴覚要因呈示により温熱要因(室温)と の相関があると言えない条件が示されたことは,「寒暑の印象」は温 熱要因の寄与が高い評定となっているとした松原ら 25)を支持する 結果である。また，両評価尺度共に基準状態に対し聴覚要因呈示状 態では相関係数が小さく, 聴覚要因の影響を受けていると考えられ る。このことは, 松原ら 30), 島田ら 31), Matsubara.et.al ${ }^{34)}$ と同様 な結果が示されたと言える。

\section{2 評価尺度の温熱要因 (室温) - 聴覚要因に対する差異}

\section{2.1 温熱要因 (室温)に対する申告値変化量の差異}

温熱要因(室温)と「涼暖の印象」「寒暑の印象」申告值変化量の関 係を表 6,7 に示す。これら(表 6,7 )の算出式は説明変数を温熱要 因(室温), 目的変数を温熱要因(室温)毎の「寒暑の印象」「涼暖の印 象」平均值とし，申告数を重みとした回帰分析結果である。

なお，表 $4 ， 5$ より「涼暖の印象」で相関係数の有意確率が $\mathrm{p}>0.1$ であった「秋の虫」「川」「風鈴」についても「寒暑の印象」と比較 するために同様に分析を行い, 参考式として算出した(表 7 網掛け部)

表 6 より「寒暑の印象」の回帰係数の有意確率は, 実験 A では「花 火」「風鈴」で有意傾向 $(\mathrm{p}<0.1)$ であったが，その他の条件では有意 $(\mathrm{p}<0.05)$ であった。実験 $\mathrm{B}, \mathrm{C} \cdot$ 暖色では, 「秋の虫」「蝉」で有意傾 向 $(\mathrm{p}<0.1)$ であったが，実験 $\mathrm{B}, \mathrm{C}$ ・寒色を含むその他の条件では有意 $(\mathrm{p}<0.05)$ であった。決定係数は, 実験 $\mathrm{A}$ では $0.86<\mathrm{R}^{\wedge} 2<0.99$ であり, 実験 $\mathrm{B}, \mathrm{C} \cdot$ 暖色では $0.42<\mathrm{R}^{\wedge} 2<0.90$, 実験 $\mathrm{B}, \mathrm{C}$ ・寒色では $0.48<\mathrm{R}^{\wedge} 2<0.89$ であった。

表 7 より「涼暖の印象」の回帰係数の有意確率は，実験 A では全 条件で有意 $(\mathrm{p}<0.05)$ であり, 決定係数は $0.93<\mathrm{R}^{\wedge} 2<0.99$ であった。 実験 $\mathrm{B}, \mathrm{C} ・$ 暖色及び寒色では共に「秋の虫」「川」「風鈴」で $\mathrm{p}>0.1$ であり，決定係数は $\mathrm{R}^{\wedge} 2<0.16$ と極端に低かった。その他の条件で は有意 $(\mathrm{p}<0.05)$ であり,決定係数は $0.44<\mathrm{R}^{\wedge} 2<0.89$ であった。

温熱要因(室温)に対する申告值変化量を, 回帰式勾配から把握す ると, 実験 A では「花火」「交通騒音」で「寒暑の印象」がより勾 配が大きく，その他の条件「基準条件」「鳥」「蝉」「川」「滝」で「涼 暖の印象」がより勾配が大きかった。実験 B,C・暖色及び寒色では,

「秋の虫」「川」「風鈴」の回帰式の信頼性は低いが，全条件で「寒 暑の印象」の勾配が大きかった。

全体の傾向として「寒暑の印象」の方がより回帰勾配が大きい。回 帰勾配差について, 共分散分析による回帰式の平行性の検定を行っ たところ, 有意差は示されなかった。このことから, 温熱要因(室温)
に対する申告值変化量に有意差が無いことが明らかとなった。

「寒暑の印象」は両端に暑い - 寒い,「涼暖の印象」は暖かい - 涼 しいが配置された尺度である。「寒暑の印象」と「涼暖の印象」が一 次元配置であれば,「涼暖の印象」の暖かい - 涼しいは「寒暑の印象」 の暑い - 寒いに包含されるため, 温熱要因(室温)との関係を示す回

表 6 「寒暑の印象」と室温の関係

\begin{tabular}{|c|c|c|c|c|c|}
\hline$\overline{\bar{T}} \bar{x}-タ$ & 聴覚要因 & $\mathrm{n}$ & 回帰式(WLS) & $\mathrm{R} 2$ & P-value \\
\hline 実験 A & $\begin{array}{c}\text { 基準条件 } \\
\text { (聴覚要因なし) }\end{array}$ & 160 & $\mathrm{Y}=-2.436+0.237 \mathrm{ta}$ & 0.986 & $\mathrm{p}<0.05$ \\
\hline 実験 A & 花火 & 80 & $\mathrm{Y}=-0.629+0.184 \mathrm{ta}$ & 0.860 & $P<0.1$ \\
\hline A & 交通騒音 & 80 & $\mathrm{Y}=0.686+0.152 \mathrm{ta}$ & 0.917 & 05 \\
\hline A & 蝉 & 80 & $\mathrm{Y}=2.217+0.106 \mathrm{ta}$ & 0.922 & $0<0.05$ \\
\hline A & 川 & 80 & $\mathrm{Y}=-1.468+0.201 \mathrm{ta}$ & 0.933 & 0.05 \\
\hline A & 滝 & 80 & $Y=-1.906+0.211 \mathrm{ta}$ & 0.907 & 0.05 \\
\hline A & 鳥 & 80 & $\mathrm{Y}=-0.426+0.165 \mathrm{ta}$ & 0.992 & .05 \\
\hline 実験 A & 風鈴 & 80 & $\mathrm{Y}=-0.175+0.162 \mathrm{ta}$ & 0.815 & $p<0.1$ \\
\hline & $\begin{array}{c}\text { 基淮条件 } \\
\text { (聴覚要因なし) }\end{array}$ & 92 & $\mathrm{Y}=0.247+0.174 \mathrm{ta}$ & 2 & 5 \\
\hline 3 C ・ 暖色 & 蝉 & 92 & $Y=3.094+0.091 \mathrm{ta}$ & 0.430 & 1 \\
\hline $3 \mathrm{C} \cdot$ & ピックハンマー & 92 & $Y=2.221+0.124 \mathrm{ta}$ & 0.665 & \\
\hline B C・暖色 & 交通騒音 & 92 & $\mathrm{Y}=1.469+0.144 \mathrm{ta}$ & 0.744 & $\mathrm{p}<0.05$ \\
\hline 3 C・暖色 & 秋の虫 & 92 & $\mathrm{Y}=2.580+0.073 \mathrm{ta}$ & 0.420 & $\mathrm{p}<0.1$ \\
\hline $3 \mathrm{C} \cdot$ & 川 & 92 & $\mathrm{Y}=2.459+0.074 \mathrm{ta}$ & 0.527 & $\mathrm{p}<0.05$ \\
\hline 80 & 風鈴 & 92 & $Y=1.802+0.094 \mathrm{ta}$ & 0.570 & 05 \\
\hline & $\begin{array}{c}\text { 基準条件 } \\
\text { (聴覚要因なし) }\end{array}$ & 92 & ta & 99 & $\mathrm{p}<0.05$ \\
\hline $\mathrm{C} \cdot$ & 蝉 & 92 & $21+0$ & 0.874 & \\
\hline B C · 寒色 & ピックハンマー & 92 & $\mathrm{Y}=1.383+0.141 \mathrm{ta}$ & 0.708 & \\
\hline $\mathrm{B} \mathrm{C} \cdot$ 寒色 & 交通騒音 & 92 & $\mathrm{Y}=1.068+0.148 \mathrm{ta}$ & 0.780 & \\
\hline C · 寒色 & 秋の虫 & 92 & $Y=1.409+0.101 \mathrm{ta}$ & 0.496 & 05 \\
\hline B C · 寒色 & 川 & 92 & $\mathrm{Y}=1.785+0.085 \mathrm{ta}$ & 0.481 & $\mathrm{p}<0.05$ \\
\hline $\mathrm{C} \cdot$ & 風鈴 & 92 & $Y=1.688+0.090 \mathrm{ta}$ & 0.648 & $p<0.05$ \\
\hline
\end{tabular}

表 7 「涼暖の印象」と室温の関係

\begin{tabular}{|c|c|c|c|c|c|}
\hline-4 & 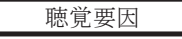 & & ) & 2 & alue \\
\hline$A$ & $\begin{array}{l}\text { 基準条件 } \\
\text { 徳覚要因な }\end{array}$ & 50 & $=-3.877+0.273 \mathrm{ta}$ & 0 & 05 \\
\hline & $\begin{array}{c}\text { 花火 } \\
\text { 交通騒音 } \\
\text { 蝉 } \\
\text { 川 } \\
\text { 滝 } \\
\text { 鳥 } \\
\text { 風鈴 }\end{array}$ & & $\begin{aligned} Y & =-1.041+0.178 \mathrm{ta} \\
Y & =0.177+0.150 \mathrm{ta} \\
Y & =0.190+0.152 \mathrm{ta} \\
Y & =-3.031+0.222 \mathrm{ta} \\
Y & =-2.784+0.214 \mathrm{ta} \\
Y & =-0.972+0.170 \mathrm{ta} \\
Y & =-2.921+0.216 \mathrm{ta}\end{aligned}$ & $\begin{array}{l}31 \\
30 \\
13 \\
2 \\
7 \\
70 \\
78 \\
\end{array}$ & \\
\hline & $\begin{array}{c}\text { 基準条件 } \\
\text { (聴覚要因なし) }\end{array}$ & 92 & 62 ta & & \\
\hline 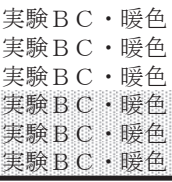 & 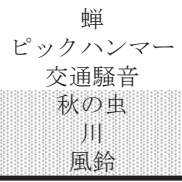 & $\begin{array}{l}92 \\
92 \\
92 \\
92\end{array}$ & 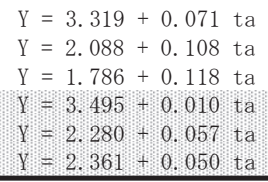 & $\begin{array}{l}0.474 \\
0.726 \\
0.005 \\
0.160 \\
0.158\end{array}$ & 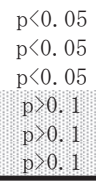 \\
\hline & $\begin{array}{c}\text { 基準条件 } \\
\text { (聴覚要因なし) }\end{array}$ & 92 & 0 & & \\
\hline 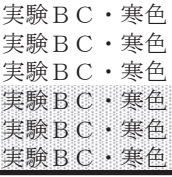 & 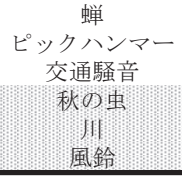 & $\begin{array}{r}92 \\
92 \\
92 \\
92 \\
92\end{array}$ & 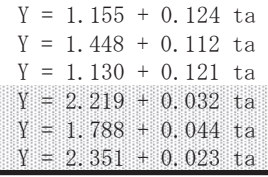 & $\begin{array}{l}0.687 \\
0.573 \\
0.526 \\
0.037 \\
0.082 \\
0.032\end{array}$ & 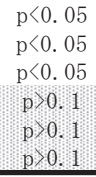 \\
\hline
\end{tabular}

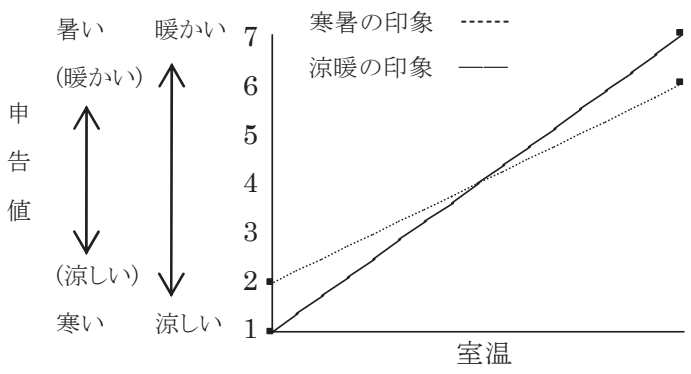

図 2 一次元配置を仮定した評価尺度の関係 
表 8 共分散分析結果 (実験 A)

\begin{tabular}{|c|c|c|c|}
\hline データ & 聴覚要因 & $\begin{array}{c}\text { 切片項差 } \\
\text { (寒暑-涼暖) }\end{array}$ & p-value \\
\hline 実験 A & $\begin{array}{c}\text { 基隻条件 } \\
\text { (聴覚要因なし) }\end{array}$ & 0.35 & $\mathrm{p}<0.05$ \\
\hline 実験 A & 川 & 0.925 & $\mathrm{p}<0.01$ \\
\hline 実験 A & 交通騒音 & 0.55 & $\mathrm{p}<0.01$ \\
\hline 実験 A & 蝉 & 0.638 & $\mathrm{p}<0.01$ \\
\hline 実験 A & 滝 & 0.775 & $\mathrm{p}<0.01$ \\
\hline 実験A & 鳥 & 0.413 & $\mathrm{p}<0.01$ \\
\hline 実験A & 風鈴 & 1.1 & $\mathrm{p}<0.01$ \\
\hline 実験A & 花火 & 0.588 & $\mathrm{p}<0.01$ \\
\hline
\end{tabular}

帰式勾配は, 図 2 に示すように「寒暑の印象」に比べ「涼暖の印象」 がより大きくなるはずである。しかし，以上の分析から評価尺度間 の回帰式勾配に有意差は無く，全体傾向として「寒暑の印象」の勾 配が大きい条件が多いため，一次元配置でないことが示唆される。 このことはKuno et.al ${ }^{26)}$ ，堀越ら 27)を支持するものであろう。

\section{2.2 温熱要因 (室温) ・聴覚要因に対する申告値水準の差異}

算出された回帰式(表 6，7)から，「寒暑の印象」対「涼暖の印象」 で共分散分析を行ったところ, 回帰式切片項に有意差が示された。 表 8〜 10 に示す。表 8〜10 中の切片項差は,共分散分析における「寒 暑の印象」一(マイナス)「涼暖の印象」の推定值である。また,実験 $\mathrm{B}, \mathrm{C} \cdot$ 暖色(表 9)及び暖色(表 10)の「秋の虫」「川」「風鈴」では回帰 係数が有意でないが $(\mathrm{p}>0.1)$ ，参考までに算出した(表 9,10 網掛け部)。 表 8 より実験 $\mathrm{A}$ では, 切片項差が基準状態を含め聴覚要因呈示状 態で有意 $(\mathrm{p}<0.05)$ であった。切片項の数值差は全てプラス值であり， 「寒暑の印象」の申告值は「涼暖の印象」に比べ高い。表 9 より実 験 $\mathrm{B}, \mathrm{C}$ ・暖色では基準状態の差は有意ではないが，全聴覚要因呈示 状態の差は有意 $(p<0.05)$ または有意傾向 $(\mathrm{p}<0.1)$ が示され，「寒暑の 印象」の申告值がより高い。表 10 より実験 $\mathrm{B}, \mathrm{C}$ ・寒色では，基準 状態を含め全聴覚要因状態で有意差 $(p<0.05)$ が示された。切片項の 数值差は, 基準状態ではマイナス值であり「涼暖の印象」の申告值 がより高いが，全聴覚要因呈示状態で「寒暑の印象」の申告值がよ り高い。

このことから基準状態では「涼暖の印象」の申告值が高い場合で も，聴覚要因呈示状態では全ての温熱要因(室温)条件において「寒 暑の印象」がより高い申告值を示すことが明らかとなった。

さらに表 8〜10より基準状態と聴覚要因呈示状態の切片項差に注 目すると，基準状態に比べ全聴覚要因状態で差が大きく，聴覚要因 呈示により両者又は一方の評価尺度に申告值変化が生じたと考えら れた。全聴覚要因条件の申告值の分布を図 $3 \sim 8$ に示す。

申告值分布から聴覚要因の傾向を把握すると，実験 $\mathrm{A}$ (図 3，4)で は「寒暑の印象」「涼暖の印象」共に「交通騒音」「蝉」は同様な申 告傾向を示し,他の聴覚要因に比心゙高い申告值分布である。「川」滝」

「風鈴」「鳥」は，前者の聴覚要因に比べ低い申告值分布であり，同 様な申告傾向を示している。「花火」の申告值は $34^{\circ} \mathrm{C}$ では交通騒 音」「蝉」の申告值に近いが，他の温熱要因(室温)条件では両者(「交 通騒音」「蝉」と「川」「滝」「風鈴」「鳥」)の中間に申告值が分布し ている。実験 $\mathrm{B}, \mathrm{C}$ 暖色(図 5,6), 寒色(図 7,8)のでは両評価尺度共 に，21 $1^{\circ}$ で聴覚要因の申告值が収束しているが，他の温熱要因（室 温）では「蟬」「ピックハンマー」「交通騒音」は同様な申告傾向を
表 10 共分散分析結果 (実験 B, C・寒色)

\begin{tabular}{|c|c|c|c|}
\hline$\vec{T}=タ$ & 聴覚要因 & $\begin{array}{c}\text { 切片項差 } \\
\text { (寒暑-涼暖) }\end{array}$ & p-value \\
\hline 実験 B C - 寒色 & $\begin{array}{c}\text { 基準条件 } \\
\text { (聴覚要因なし) }\end{array}$ & -0.587 & $\mathrm{p}<0.01$ \\
\hline 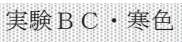 & 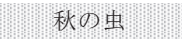 & 1.043 & $0,0,01$ \\
\hline 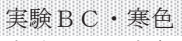 & 11 & 1,076 & (⿻) \\
\hline 実験 B C. 寒色 & 交通騒音 & 0.663 & $p<0.01$ \\
\hline 実験 B C - 寒色 & 蟬 & 0.576 & $\mathrm{p}<0.01$ \\
\hline 実験 B C - 寒色 & ピックハンマー & 0.717 & $p<0.01$ \\
\hline 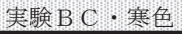 & 風基金位 & 1,141 & {$[\mathrm{p} \times 0,01$} \\
\hline
\end{tabular}

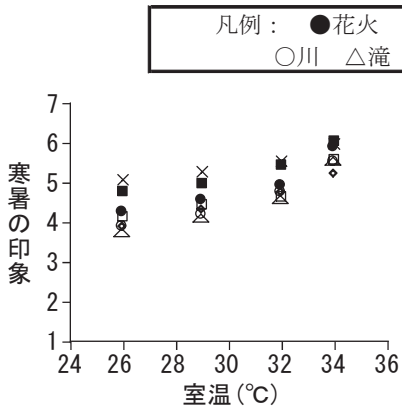

図 3 寒暑の印象 (実験 $\mathrm{A}$ )
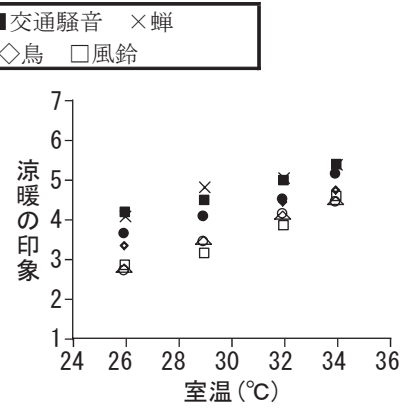

図 4 涼暖の印象 (実験 A)

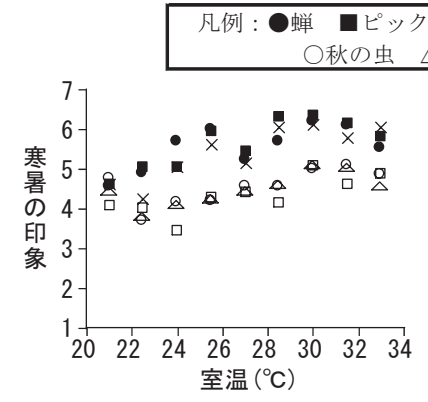

図 5 寒暑の印象 (実験 B, C・暖色)

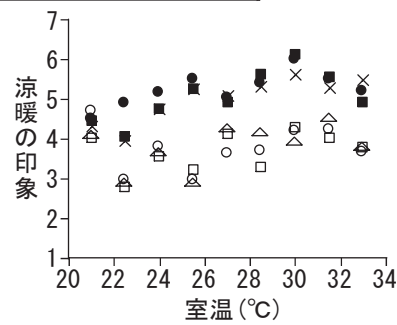

図 6 涼暖の印象 (実験 B, C・暖色)

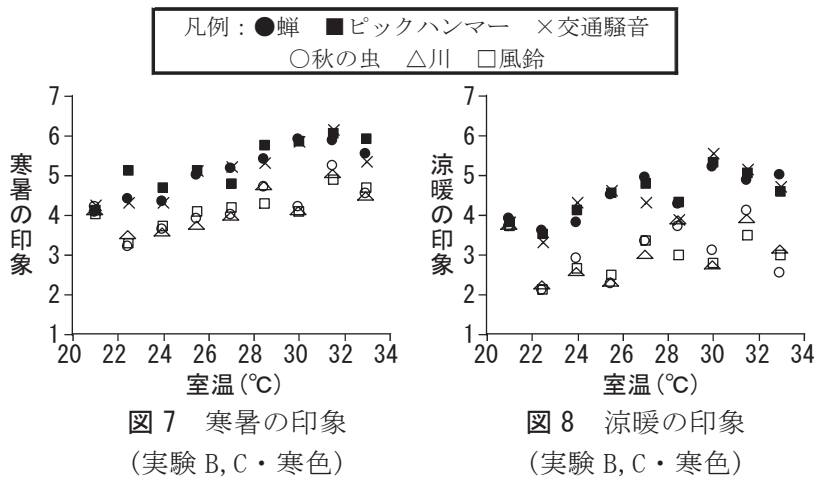

示し，他の聴覚要因に比べ高い申告值分布である。「秋の虫」「川」 「風鈴」では，前者の聴覚要因に比心゙低い申告值分布であり，同様 な申告傾向を示している。これら申告值分布の傾向から，相対的に 高い申告值分布の聴覚要因を暖かい側の聴覚要因とし, 低い申告值 分布の聴覚要因を涼しい側の聴覚要因としてグループ分けを行った。 実験 A では「交通騒音」「蝉」を暖かい側の聴覚要因，「川」「滝」 「風鈴」「鳥」を涼しい側の聴覚要因とした。また，「花火」は申告

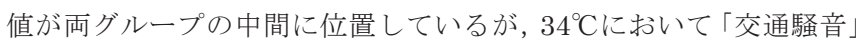




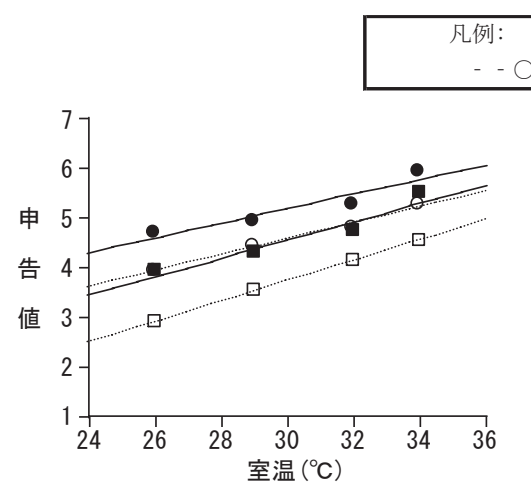

図 9 グループ別の室温との関係 (実験 A)

- 寒暑の印象·暖かい側 - - - 寒暑の印象·涼しい側 涼暖の印象·暖かい側 - - $\square-$ - 涼暖の印象·涼しい側

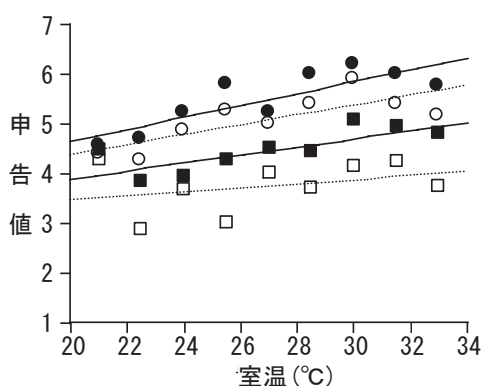

図 10 グループ別の室温との関係 (実験 B, C・暖色)

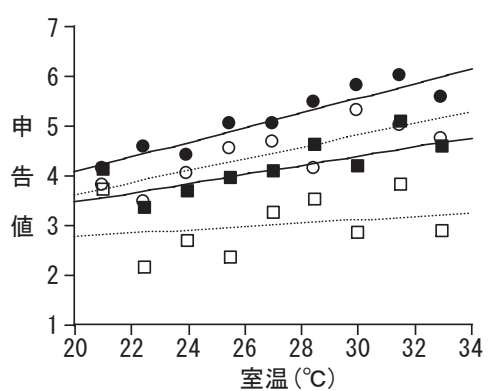

図 11 グループ別の室温との関係 (実験 B, C・寒色)
表 11 グループ別の室温との関係(回帰式データ)

\begin{tabular}{|c|c|c|c|c|c|}
\hline $\bar{T}-\not y$ & 評価尺度 & グループ & 回帰式(WLS) & R2 & P-value \\
\hline 実験A & 寒暑の印象 & 暖かい側 & $\mathrm{Y}=0.76+0.15 \mathrm{ta}$ & 0.89 & $\mathrm{p}<0.1$ \\
\hline 実験A & 寒暑の印象 & 涼しい側 & $\mathrm{Y}=-0.99+0.18 \mathrm{ta}$ & 0.93 & $\mathrm{p}<0.05$ \\
\hline 実験A & 涼暖の印象 & 暖かい側 & $\mathrm{Y}=-0.22+0.16 \mathrm{ta}$ & 0.98 & $\mathrm{p}<0.01$ \\
\hline 実験 A & 涼暖の印象 & 涼しい側 & $\mathrm{Y}=-2.43+0.21 \mathrm{ta}$ & 0.99 & $\mathrm{p}<0.01$ \\
\hline 実験 B C - 暖色 & 寒暑の印象 & 暖かい側 & $\mathrm{Y}=2.26+0.12 \mathrm{ta}$ & 0.68 & $\mathrm{p}<0.01$ \\
\hline 実験 B C · 暖色 & 寒暑の印象 & 涼しい側 & $\mathrm{Y}=2.28+0.08 \mathrm{ta}$ & 0.59 & $\mathrm{p}<0.05$ \\
\hline 実験 B C - 暖色 & 涼暖の印象 & 暖かい側 & $\mathrm{Y}=2.39+0.1 \mathrm{ta}$ & 0.6 & $p<0.05$ \\
\hline 実験 B C - 暖色 & 涼暖の印象 & 涼しい側 & $\mathrm{Y}=2.71+0.04 \mathrm{ta}$ & 0.1 & $\mathrm{p}>0.1$ \\
\hline 実験 B C - 寒色 & 寒暑の印象 & 暖かい側 & $\mathrm{Y}=1.12+0.15 \mathrm{ta}$ & 0.87 & $\mathrm{p}<0.01$ \\
\hline 実験 B C - 寒色 & 寒暑の印象 & 涼しい側 & $\mathrm{Y}=1.63+0.09 \mathrm{ta}$ & 0.56 & $\mathrm{p}<0.05$ \\
\hline 実験 B C · 寒色 & 涼暖の印象 & 暖かい側 & $\mathrm{Y}=1.24+0.12 \mathrm{ta}$ & 0.65 & $p<0.01$ \\
\hline 実験 B C - 寒色 & 涼暖の印象 & 涼しい側 & $\mathrm{Y}=2.12+0.03 \mathrm{ta}$ & 0.05 & $\mathrm{p}>0.1$ \\
\hline
\end{tabular}

「蝉」の申告值に近いため, 暖かい側の聴覚要因とした。実験 B,C では「蝉」「ピックハンマー」「交通騒音」を暖かい側の聴覚要因, 「秋の虫」「川」「風鈴」を涼しい側の聴覚要因とした。

なお, これらのグループ分けは, 申告值分布の全体傾向に注目し た分類であり，聴覚要因の影響を把握するための便宜上の分類であ ることを断っておく。これら 2 つのグループの回帰式を図 9 11 及 び表 11 に示す。

聴覚要因呈示状態における実験環境条件は,「寒暑の印象」の申告 最低值から実験 $\mathrm{A}$ (図 3,4$) 26^{\circ} \mathrm{C}$ の滝」で 3.7 , 実験 $\mathrm{B}, \mathrm{C}$ ・暖色(図 5,6 ) では $24^{\circ} \mathrm{C}$ の風鈴」で 3.5 , 寒色(図 7,8 )では $22.5^{\circ} \mathrm{C}$ の秋の虫」で 3.2 であることから, 中立付近(申告最低值)から暖かい又は暑い状態 であることが推測される。

全体として, 回帰式の当てはまりは良いといえる（表 11）。実験 $\mathrm{B}, \mathrm{C}$ の「秋の虫」「川」「風鈴」の涼しい側の聴覚要因の回帰式は, 決定係数が低く回帰係数の有意確率が $\mathrm{p}>0.1$ の結果を示した。

図 9-11 より「寒暑の印象」の「暖かい側の聴覚要因」の申告值は, 図 11 ・室温 $21.0^{\circ} \mathrm{C}$ より 4 以上であり,「涼暖の印象」の同グループ の全ての温熱要因(室温)条件に対して高い申告值を示した(共分散 分析にて切片項差 $\mathrm{p}<0.05)$ 。また, 「寒暑の印象」の「涼しい側の聴 覚要因」の申告值は図 11 ・室温 $22.5^{\circ} \mathrm{C}$ より 3.3 以上であり,「涼暖の 印象」の同グループの全ての温熱要因(室温) 条件に対して高い申告 值を示した(共分散分析にて切片項差 $\mathrm{p}<0.05$ )。

以上の結果より，「寒暑の印象」が中立付近から暖かい又は暑いと 申告された実験環境条件下で「涼暖の印象」の申告值が常に小さいこ とから, 聴覚要因呈示状態において「涼暖の印象」は,「寒暑の印象」
表 12 一元配置分散分析結果

\begin{tabular}{|c|c|c|c|}
\hline $\bar{\tau}-タ$ & 聴覚要因 & 温熱要因 (室温) & p-value \\
\hline 実験BC·暖色 & 秋の虫 & $22.5^{\circ} \mathrm{C}$ & $\mathrm{p}<0.05$ \\
\hline 実験BC·暖色 & 秋の虫 & $25.5^{\circ} \mathrm{C}$ & $\mathrm{p}<0.05$ \\
\hline 実験BC·暖色 & 秋の虫 & 27. $0^{\circ} \mathrm{C}$ & $\mathrm{p}<0.01$ \\
\hline 実験BC·暖色 & 秋の虫 & $33.0^{\circ} \mathrm{C}$ & $\mathrm{p}<0.1$ \\
\hline 実験BC·暖色 & 川 & $22.5^{\circ} \mathrm{C}$ & $\mathrm{p}<0.05$ \\
\hline 実験BC·暖色 & 川 & $25.5^{\circ} \mathrm{C}$ & $\mathrm{p}<0.05$ \\
\hline 実験BC·暖色 & 川 & $30.0^{\circ} \mathrm{C}$ & $\mathrm{p}<0.1$ \\
\hline 実験BC·暖色 & 風鈴 & $22.5^{\circ} \mathrm{C}$ & $\mathrm{p}<0.01$ \\
\hline 実験BC·暖色 & 風鈴 & $25.5^{\circ} \mathrm{C}$ & $\mathrm{p}<0.05$ \\
\hline 実験BC·暖色 & 風鈴 & $33.0^{\circ} \mathrm{C}$ & $\mathrm{p}<0.1$ \\
\hline 実験BC·寒色 & 秋の虫 & $22.5^{\circ} \mathrm{C}$ & $p<0.05$ \\
\hline 実験BC·寒色 & 秋の虫 & $24.0^{\circ} \mathrm{C}$ & $\mathrm{p}<0.1$ \\
\hline 実験BC·寒色 & 秋の虫 & $25.5^{\circ} \mathrm{C}$ & $\mathrm{p}<0.01$ \\
\hline 実験BC·寒色 & 秋の虫 & $27.0^{\circ} \mathrm{C}$ & $\mathrm{p}<0.1$ \\
\hline 実験BC·寒色 & 秋の虫 & $33.0^{\circ} \mathrm{C}$ & $\mathrm{p}<0.01$ \\
\hline 実験BC·寒色 & 川 & $22.5^{\circ} \mathrm{C}$ & $\mathrm{p}<0.01$ \\
\hline 実験BC·寒色 & 川 & $24.0^{\circ} \mathrm{C}$ & $\mathrm{p}<0.05$ \\
\hline 実験BC·寒色 & 川 & $25.5^{\circ} \mathrm{C}$ & $\mathrm{p}<0.05$ \\
\hline 実験BC·寒色 & 川 & $27.0^{\circ} \mathrm{C}$ & $\mathrm{p}<0.05$ \\
\hline 実験BC·寒色 & 川 & $30.0^{\circ} \mathrm{C}$ & $\mathrm{p}<0.05$ \\
\hline 実験BC·寒色 & 川 & $33.0^{\circ} \mathrm{C}$ & $\mathrm{p}<0.01$ \\
\hline 実験BC·寒色 & 風鈴 & $22.5^{\circ} \mathrm{C}$ & $\mathrm{p}<0.01$ \\
\hline 実験BC·寒色 & 風鈴 & $24.0^{\circ} \mathrm{C}$ & $\mathrm{p}<0.05$ \\
\hline 実験BC·寒色 & 風鈴 & $25.5^{\circ} \mathrm{C}$ & $\mathrm{p}<0.01$ \\
\hline 実験BC·寒色 & 風鈴 & $27.0^{\circ} \mathrm{C}$ & $\mathrm{p}<0.1$ \\
\hline 実験BC·寒色 & 風鈴 & $28.5^{\circ} \mathrm{C}$ & $\mathrm{p}<0.1$ \\
\hline 実験BC·寒色 & 風鈴 & $30.0^{\circ} \mathrm{C}$ & $\mathrm{p}<0.1$ \\
\hline 実験BC·寒色 & 風鈴 & $33.0^{\circ} \mathrm{C}$ & $\mathrm{p}<0.05$ \\
\hline
\end{tabular}

に比べ温熱要因(室温)の影響が小さい評価尺度と考えられる。

温熱要因(室温)に対する影響差は, 評価尺度の相関係数及び申告 值変化量の差には示されなかったが, 評価尺度の申告值水準の差に 顕著に示されたと言えよう。また, 図 2 との比較から, このことは 「寒暑の印象」と「涼暖の印象」が一次元配置でないことを示唆するも のである。

\section{2.3 相関係数・回帰係数が有意でない条件について}

聴覚要因呈示状態において,「涼暖の印象」で相関及び回帰係数が 有意でない条件(「秋の虫」「川」「風鈴」)があることを示した。これ らは温熱要因(室温)のみでは説明できないことを示唆しており,こ の結果は参考程度にとどまる。そこでこれらの条件に適合する分析 を行い, 先の「涼暖の印象」は「寒暑の印象」に比心゙温熱要因(室温) の影響がより小さいという結果について考察する。さらに, これら の条件における温熱要因(室温) と「涼暖の印象」の非一次線形関係 についての考察を行う。分析方法としては, 実験 $\mathrm{BC} ・$ 暖色, 寒色 


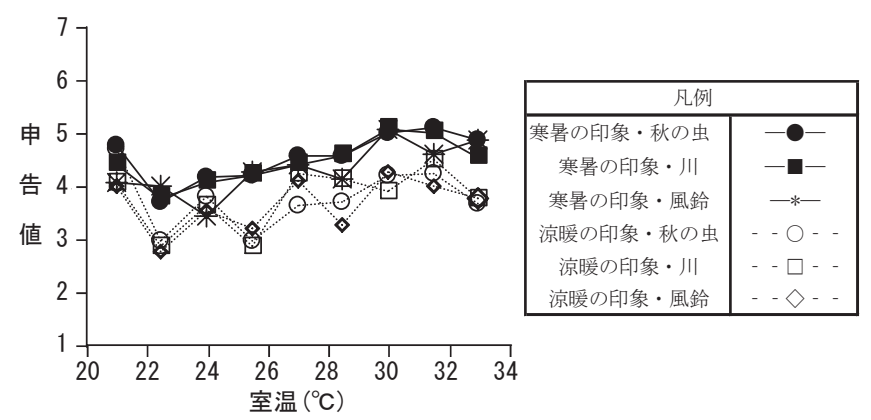

図 12 申告值と温熱要因 (室温)の関係 (実験 B, C・暖色)

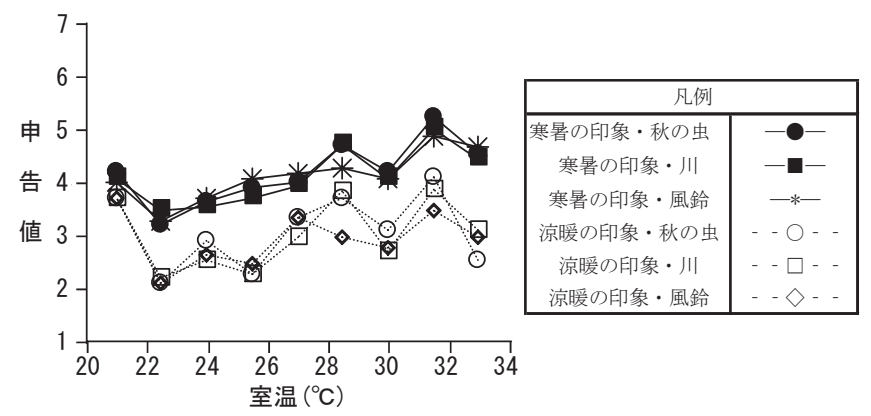

図 13 申告値と温熱要因 (室温)の関係 (実験 B, C・寒色)

の「秋の虫」「川」「風鈴」それぞれの「涼暖の印象」と「寒暑の印 象」の申告值差を温熱要因(室温)毎で把握する $\mathrm{t}$ 検定である。算出 結果を表 12 , 図 12,13 に示す。

実験 B,C·暖色(図 12) より「風鈴」の $24^{\circ} \mathrm{C}$ で「寒暑の印象」に比心゙ 「涼暖の印象」の申告值が 0.1 ポイント高いが, その他の温熱要因(室 温)条件で「寒暑の印象」の申告值がより高い。実験 B,C·寒色(図 13) では全温熱要因(室温)条件で「寒暑の印象」の申告值がより高い。「寒 暑の印象」と「涼暖の印象」の申告值差(表 12)は実験 BC·暖色の「秋 の虫」では, 温熱要因(室温)9 条件中 4 条件,「川」では 3 条件「風 鈴」では 3 条件で, 実験 BC·寒色の「秋の虫」では温熱要因(室温)9 条件中 5 条件,「川」では 6 条件,「風鈴」では 7 条件で有意差 $(\mathrm{p}<0.05)$ 又は有意差傾向 $(\mathrm{p}<0.1)$ が示された。

「寒暑の印象」は実験 $\mathrm{BC}$ ・暖色(図 12)「風鈴」の $24^{\circ} \mathrm{C}$ で申告值 $=3.5$ 実験 $\mathrm{BC}$ - 寒色(図 13)「秋の虫」の $22.5^{\circ} \mathrm{C}$ で申告值 $=3.2$ が最も低く, 実験 $\mathrm{BC} \cdot$ 暖色(図 12)「秋の虫」の $31.5^{\circ} \mathrm{C}$ で申告值 $=5.13$, 実験 $\mathrm{BC} \cdot$ 寒色(図 13)「秋の虫」の $31.5^{\circ} \mathrm{C}$ で申告值 $=5.25$ が最も高く, 聴覚要因 呈示状態における実験環境条件としては，中立付近から暖かい状態 であったことが推測される。

以上の結果から，「秋の虫」「川」「風鈴」において「寒暑の印象」 の申告值が中立付近から暖かい環境下において「涼暖の印象」の申告 值が小さく,「涼暖の印象」は温熱要因(室温)の影響がより小さいと 考えられ，3.2.2 と同様の結果が示された。

「涼暖の印象」で相関及び回帰係数が有意でない(「秋の虫」「川」「風 鈴」) 原因について, 実験 B,C・暖色(図 12) 寒色, (図 13)の $21^{\circ} \mathrm{C} て ゙$, 聴覚要因条件に関わらず申告值が収束している。前者では「寒暑の印 象」で申告值 $4.1 \sim 4.8$, 「涼暖の印象」で申告值 $4 \sim 4.7$, 後者では「寒 暑の印象」で申告值 $4 \sim 4.2$, 「涼暖の印象」で申告值 3.7 に全聴覚要 因条件が収束している。「涼暖の印象」(図 6, 図 8)では $21^{\circ} \mathrm{C}$ を除いた
回帰係数は実験 $\mathrm{B}, \mathrm{C}$ ·暖色の「秋の虫」「風鈴」, 実験 $\mathrm{B}, \mathrm{C}$ ·寒色の「川」 「風鈴」で $\mathrm{p}<0.1$ であった(実験 $\mathrm{B}, \mathrm{C} \cdot$ 暖色「川」は $\mathrm{p}=0.1$, 実験 $\mathrm{B}, \mathrm{C} \cdot$ 寒 色「秋の虫」は $\mathrm{p}=0.22$ )ことからも, 温熱要因(室温) $21^{\circ} \mathrm{C}$ こおける「涼 暖の印象」申告值の影響が強いことが分かる。

「涼暖の印象」だけでなく「寒暑の印象」に温熱要因(室温), 聴覚要 因(音), 視覚要因(映像・照度)が複雑に影響し合っている事は, 島田 ら 31)や Gassho et al ${ }^{35)}$, 長野ら 36)で報告されており, 図 12 や図 13, さらに 3.2 .2 の図 5 及び図 7 の「寒暑の印象」でも同様の傾向である が，「涼暖の印象」の様に温熱要因(室温)との一次線形関係を崩すほ どではなく,「涼暖の印象」では温熱要因(室温)と聴覚要因との組み 合わせによる影響が，より顕著に現れる評価尺度と考えられる。さ らに, 「涼暖の印象」では, 特定の温熱要因(室温)条件において, こ れら特定の聴覚要因の影響を受けないマスキング効果 ${ }^{8)}$ (37)に似た反 応を示した可能性も考えられよう。

また, 3.2 .2 の図 $5 \sim 8$ 及び図 10 , 図 11 の実験 B,C「寒暑の印象」 「涼暖の印象」において温熱要因（室温）が $30^{\circ} \mathrm{C}$ を超えると申告值 が下がる傾向がある。この場合, 聴覚要因が温熱要因に対する反応 に何らかの影響を与えた可能性が考えられる。しかしこれらの点に ついては, 本研究では推測の域を出ない。これらの解釈については 今後の検討課題としたい。

\section{2.4 聴覚要因の影響}

「涼暖の印象」の「暖かい側の聴覚要因グループ」と「涼しい側 の聴覚要因グループ」の申告值水淮差は, 「寒暑の印象」の両グルー プの申告值水準差に比べ大きい傾向が見られた(図 9〜11)。これら の差を共分散分析により切片項差の推定值を算出したところ, 実験 $\mathrm{A}$ (図 9)では「寒暑の印象」は 0.63 に対し「涼暖の印象」では 0.84 であった。実験 B,C・暖色(図 10)では「寒暑の印象」は 1.03 に対し「涼 暖の印象」では 1.3 であった。実験 B,C・寒色(図 11)では「寒暑の 印象」は 0.97 に対し「涼暖の印象」は 1.42 であり，いずれも「涼暖 の印象」の切片項差がより大きい。

さらに「寒暑の印象」の「涼しい側の聴覚要因グループ」と「暖 かい側の聴覚要因グループ」の申告值差と「涼暖の印象」の「涼し い側の聴覚要因グループ」と「暖かい側の聴覚要因グループ」の申 告值差の差を, 聴覚要因(涼しい側・暖かい側の聴覚要因グループ) と評価尺度(「寒暑の印象」・「涼暖の印象」)の 2 元配置分散分析の 交互作用検定にて把握したところ(この際，交互作用が有意な場合， 評価尺度間で聴覚要因グループの申告值の差に差があると解釈して いる)実験 $\mathrm{A}$ (図 9)では有意差は示されなかったが, 実験 B,C·暖色(図 10 )の $25.5^{\circ} \mathrm{C}$ で有意差傾向 $(\mathrm{p}<0.1$ )が示された。実験 B,C・寒色(図 11) では $24^{\circ} \mathrm{C}, 30^{\circ} \mathrm{C}, 33^{\circ} \mathrm{C}$ で有意差傾向 $(\mathrm{p}<0.1)$ が示され, $25.5^{\circ} \mathrm{C}$ で有 意差 $(\mathrm{p}<0.05)$ が示された。

以上より,「涼暖の印象」と「寒暑の印象」の聴覚要因グループ申 告值差に差が示され, 且つ「涼暖の印象」の申告值差がより大きいこ とから,「涼暖の印象」は聴覚要因の影響がより大きいと考えられる。

一方で, 有意差が示された条件は実験環境条件(温熱要因(室温), 視覚要因(暖色・寒色等))により異なった。この原因としては, 聴覚 要因や温熱要因, 視覚要因の組合せによる影響が考える。実験 B,C・ 暖色(図 10) と実験 B,C・寒色(図 11)から聴覚要因(暖かい側・涼しい 側) と温熱要因(室温) と視覚要因(暖色・寒色) と各評価尺度との 3 元 
配置分散分析を行ったところ, 両評価尺度共に温熱要因と聴覚要因 の交互作用が有意であった $(\mathrm{p}<0.01)$ 。

このことは,「涼暖の印象」と「寒暑の印象」の聴覚要因の影響差は 温熱要因との組み合わせにより顕著(有意)に示されるということで ある。つまり「涼暖の印象」は聴覚要因の影響を受け易いが，「寒暑の 印象」との聴覚要因の影響差が顕著に示されるのは温熱要因条件に 制限されると考えられる。先に「涼暖の印象」は温熱要因(室温)と 聴覚要因との組み合わせによる影響がより顕著であることを述べた。 「寒暑の印象」との聴覚要因の影響差が, 温熱要因条件により異な るのは, 組み合わせによる影響差が, ある温熱要因条件下で表れ, このことが聴覚要因の影響に顕著な差を生じさせた 1 つの要因であ る可能性がある。

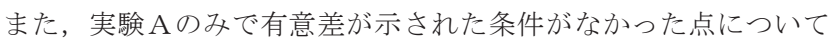
は, 実験 B,C との最も異なる実験環境条件として照度差がある。照 度が両評価尺度に影響することは長野ら 36 により報告されおり，実 験 A では 5lx に対し実験 B,C では 1000lx であった。本研究では実 験間での比較は困難であると判断しデータ解析を控えたが, 聴覚要 因の影響差に照度が影響している可能性がある。

3.2 .2 及び 3.2.3 の結果から, 温熱要因や聴覚要因のある複合環境 下において,「涼暖の印象」は「寒暑の印象」に比べ温熱要因の影響が 小さく, 聴覚要因の影響が大きいと言えよう。

この理由として一つの推測を行うと, 兼子ら ${ }^{38}$ は『日本人は暖か さ涼しさを温熱感覚の程度を表すだけでなく快適性を含めた表現と して捉えており，暑さ寒さとは違う概念として捉えている』と報告 している(他に兼子ら $\left.{ }^{39}\right)$ )。筆者らの研究(西應ら 40 ))では被験者の各 環境要因への注意の向け方の違いが環境要因に対する評定に影響を もたらすことを報告している。同じく筆者ら(島田ら ${ }^{31}$ ) は複合環境 実験から『環境要因に対する反応の違いは評価対象に分配される注 意資源の量に起因していると考えられる』と報告している。「暑い」 「寒い」と「暖かい」「涼しい」の捉え方の違い, 寸なわち「涼暖の 印象」を温熱感覚の程度を表すだけでない概念として捉えたことに より,「寒暑の印象」に比心゙温熱要因に配分される注意資源が減少し, 聴覚要因に注意資源がより多く配分された事が，両評価尺度の評定 差として表れたと推測される。

\section{4. まとめ}

本研究では複合環境評価実験における「寒暑の印象」と「涼暖の 印象」の尺度比較を行った。その結果を以下に示す。

1)温熱要因(室温)と各評価尺度の相関係数は, 「寒暑の印象」と「涼 暖の印象」の間に顕著な差は無かった。しかし，聴覚要因を呈示 した場合は両評価尺度の相関係数が小さいので, 聴覚要因の影響 を受けていることは明らかである。また「涼暖の印象」ではいく つかの聴覚要因を呈示した場合には温熱要因（室温）との相関が あると言えないため,「涼暖の印象」は温熱要因(室温)の一環境要 因のみではなく聴覚要因の影響を明確に受ける評価尺度と考え られた。

2)温熱要因(室温)と各評価尺度の関係を回帰式により把握したとこ ろ, 回帰勾配は「寒暑の印象」が大きい条件が多かった。このこ とから「寒暑の印象」と「涼暖の印象」は一次元配置で無い可能 性を示唆した。
3)「寒暑の印象」と「涼暖の印象」の申告值水準差から, 聴覚要因 呈示状態において「涼暖の印象」は「寒暑の印象」に比べ申告值 が低く,この時「寒暑の印象」から環境条件は中立付近又は暖か い状態であったことから,「涼暖の印象」は「寒暑の印象」に比べ 温熱要因の影響が小さいと考えられた。また,このことからも「寒 暑の印象」と「涼暖の印象」は一次元配置で無いと推測された。 4)「涼暖の印象」の「暖かい側の聴覚要因」と「涼しい側の聴覚要 因」の申告值水準差は「寒暑の印象」より大きく,「涼暖の印象」 は「寒暑の印象」より聴覚要因の影響が大きいと考えられた。

5)「涼暖の印象」では, 特定の聴覚要因（「秋の虫」「川」「風鈴」）に より, 温熱要因の室温との関係が一次の線形関係で無くなること が明らかとなった。このことについて,「涼暖の印象」では温熱要 因（室温）と聴覚要因との組み合わせによる影響がより顕著であ った事が一つの原因と考えられた。しかし，この詳細なメカニズ ムは本研究では明らかとなっておらず，今後の課題とする。

6)「涼暖の印象」では聴覚要因の影響をより受け易いが，「寒暑の印 象」との差が顕著に示されるのは温熱要因条件で異なった。この 事は, 両評価尺度の温熱要因と聴覚要因との組み合わせによる影 響差が，ある温熱要因条件下で表れたことが，聴覚要因の影響に 顕著な差を生じさせた 1 つの要因であることを示唆した。

本研究では両評価尺度の違いを明らかとすることを目的とし，分 析結果の全体傾向に注目した。その結果，「涼暖の印象」は「寒暑の 印象」と比べ, 温熱要因及び聴覚要因の影響度合いに差があること が明らかとなった。一方で, 温熱要因や聴覚要因の条件により, そ の影響度合いの差には違いが見受けられた。さらにこのことに照度 の条件も影響している可能性もある。また本研究では個人差の影響 は考慮していない。両評価尺度の差異を明らかと寸るにはこれらを 含めた, より詳細な分析が必要であろう。しかし, 本研究で非特異 的評価尺度間の差異を具体的に示したことは，これまでの複合環境 評価実験の知見をさらに進めたものであり，意義のある結果と言え る。

\section{謝辞}

実験にご協力いただいた被験者の皆様に感謝いたします。なお， 本研究の一部に文部科学省科学研究費補助金基盤研究 $\mathrm{B}($ 代表 : 松原 斎樹 課題番号 21300270)の助成を受けた。

\section{参考文献}

1）堀江悟郎・桜井美政・松原斎樹：室内空間における各種環境要因の複合 効果について -- 夏期主観申告について--, 日本生気象学会雑誌, 18(3), p.44, 1981.

2）堀江悟郎 - 桜井美政 - 野口太郎 - 松原斎樹 - 中川嘉久 - 高階和夫 - 松原 誠二: 室内環境要因の複合作用に関する研究（そのI, 夏季における数量 化理論 2 類の結果について), 日本建築学会近畿支部研究報告集（計画系）, 22 号, pp.41-44, 1982.

3）堀江悟郎 - 桜井美政 - 野口太郎 - 松原斎樹 - 中川嘉久 - 高階和夫 - 松原 誠二：室内環境要因の複合作用に関する研究（そのII, 冬季における数量 化理論 2 類の結果について), 日本建築学会近畿支部研究報告集（計画系）, 22 号, pp.45-48, 1982.

4）堀江悟郎 - 桜井美政 - 野口太郎 - 松原斎樹 - 中川嘉久 - 高階和夫 - 松原 誠二：室内環境要因の複合作用に関する研究（そのIII, 作業成績と生理量 
の結果について）,日本建築学会近畿支部研究報告集（計画系）, 22号, pp.49-52, 1982 .

5) Horie,G., Sakurai,Y., Matsubara,N. and Noguchi,T.: Synthesized evaluation of different kinds of environmental stresses in a room. Abstracts, 10th International Congress of Biometeorology, p.86, Tokyo 1984.

6) Horie,G., Sakurai,Y., Matsubara,N. and Noguchi,T.: Combined effects of different kinds of environmental stresses in a room on human performance. Abstracts, 10th International Congress of Biometeorology, p.87, Tokyo, 1984.

7) Horie,G., Sakurai,Y., Noguchi,T. and Matsubara,N.: Synthesized evaluation of noise, lighting and thermal conditions in a room. Proceedings of the International Conference of Noise Control Engineering (Krakow), pp.491-496, 1985.

8）堀江悟郎, 桜井美政, 松原斎樹, 野口太郎: 室内における異種環境要因 がもたらす不快さの加算的表現. 日本建築学会計画系論文報告集, No.387, pp.1-7,1988.5

9）堀江悟郎, 桜井美政, 松原斎樹, 野口太郎: 加算モデルによる異種環境 要因の総合評価の予測, 日本建築学会計画系論文報告集, No.402, pp.1-7, 1989.8

10）松原斎樹：建築の複合環境評価研究における非特異的尺度の意義, 日本 建築学会東海支部研究報告集，25 号，pp.233-236， 1987.

11) Matsubara,N., Ito,K., Gassho,A. and Kurazumi,Y.: Importance of nonspecific scale and the additive model in the evaluation study of the combined environment, Archives of Complex Environmental Studies, 7, pp.45-54, 1995. (Proc. 6th ICCEF 94, Toyama Japan , 25-28 September, pp.121- 129, 1994.)

12) Morgenson,M.F and English,B.H: The apparent warmth of colors, Amer, J. Psychol. 36, pp.192-206, 1926

13) Houghten,F.C., Olson,H.T. and Suciu, J.: Sensation of warmth as affected by the color of the environment, Illuminating Engineering, 35, pp.908-914, 1940

14) Berry,P.C.: Effect of colored illumination upon perceived temperature, J. Appl. Psychol., 45, pp.248-250, 1960

15) Bennett,C.A. and Rey,P.: What's so hot about red? Human Factors, 14(2), pp.149-154, 1972

16) Fanger,P.O., Breum, N.O. and Jerking, E.: Can color and noise influence man's thermal comfort? Ergonomics, 20, pp.11-18, 1977

17) Greene, T.C. and Bell, P.C.: Additional considerations concerning the effects of 'warm' and 'cool' wall colors on energy conservation, Ergonomics, 23, pp.949-954, 1984

18）大野秀夫, 久野覚, 木田光郎：中原信生:居住者の温冷感覚に及ぼす温熱 環境と色彩環境の複合効果に関する研究，日本建築学会計画系論文報告集， No374, pp.8-18, 1987.4

19）岩宮眞一郎：音環境と景観の相互作用-景観の印象に及ぼす音環境の影響 と音環境の印象に及ぼす景観の影響-, 生理人類誌, 11(1), pp.51-59, 1992

20）中村肇，垣鍔直，沖允人：気温が色温度の好ましさに及ぼす影響，日本建 築学会計画系論文集, No.535, pp.1-7, 2000.9

21) de Arruda MP, Gonçalves EC, Schneider MP, da Costa da Silva AL, Morielle-Versute E.: An alternative genotyping method using dye-labeled universal primer to reduce unspecific amplifications. Mol Biol Rep. 37(4), pp.2031-2036, 2010

22) Adamson IY, Bakowska J, Bowden DH. : Mesothelial cell proliferation: a nonspecific response to lung injury associated with fibrosis. Am J Respir Cell Mol Biol. 10(3), pp.253-258, 1994

23) Hull D, Rennie P, Noronha A, Poore C, Harrington N, Fearnley V, Passàli D., Effects of creating a non-specific, virus-hostile environment in the nasopharynx on symptoms and duration of common cold. Acta Otorhinolaryngol Ital. 27(2): pp.73-77, 2007

24）田多井吉之助：新版 ストレス, 創元社, 1980

25）松原斎樹,伊藤香苗, 藏澄美仁, 合掌顕,長野和雄 : 色彩と室温の複合環境に 対する特異的及び非特異的評価, 日本建築学会計画系論文集, No.535, pp.39-45, 2000.9

26) Kuno,S., Ohno,H. and Nakahara,N.: A two dimenshional model expressing thermal sensation in transient conditions, ASHRAE Trans. , 93(2), pp.396-406, 1987

27）堀越哲美，磯田憲生，小林陽太郎：風洞内温熱環境条件の人体に及ぼす 影響に関する実験的検討(男子裸体)その 2 夏季平均皮膚温と温冷感申告,空 気調和衛生工学学術講演会論文集, pp.27-30, 1974

28）大野秀夫, 久野覚：温熱環境評価用語の日本語と英語の対応について, 日本建築学会大会学術講演梗概集 D 環境工学, pp.451-452, 1992

29）兼子朋也，堀越哲美：尺度付言語選択法を用いた日本人の温熱環境に対 する心理的評価に関する研究，日本建築学会計画系論文集，No.543， pp.93-99, 2001.5

30）松原斎樹，島田理良，蔵澄美仁，合掌顕，飛田国人：温熱，視覚，聴覚 要因の複合環境評価実験において環境要因を付加することの影響-注意概 念による考察-, 日本建築学会環境系論文集, No.611, pp.83-89,2007.1

31）島田理良, 松原斎樹, 藏澄美仁, 合掌顕, 飛田国人：温熱・視覚・聴覚 要因の複合環境評価実験における特異的・非特異的評価尺度の違い - - 注 意概念による考察--, 日本建築学会環境系論文集, 628号, pp.807-813, 2008.6

32）須藤由佳子，松原斎樹，合掌顕，藏澄美仁，小東敬典，青地奈央，飛田 国人: 室温, 色彩による複合環境の心理評一注意を要因とした実験結果一, 日本建築学会環境系論文集, 630 号, pp.1037-1043, 2008.8

33）松原斎樹, 合掌顕, 蔵澄美仁, 澤島智明, 大和義明 : 視覚刺激と聴覚刺 激が温熱感覚にもたらす心理効果，日生気誌，40(S)，pp.249-259，2004

34) Matubara, N., Gassho, A., Kurazumi, Y.: Combined effect of ambient temperature and color on thermal sensation, Proceedings of $3^{\text {rd }}$ International Conference on Human-Environment System, Tokyo, Japan, September 12-15, pp.353-356, 2005

35) Gassho, A., Matubara, N. and Kurazumi, Y.: Combined effect of environmental sounds, temperature and color on thermal sensation, Proceedings of $3^{\text {rd }}$ International Conference on Human-Environment System, Tokyo, September 12-15, pp.485-490, 2005

36) 長野和雄, 松原斎樹, 蔵澄美仁, 合掌顕, 伊藤香苗, 鳴海大典 : 環境音 · 室温・照度の複合環境評価に関する基礎的考察 特異的評価と非特異的評 価の関係，日本建築学会計画系論文集，No490, pp.55-61, 1996.12

37) Yamazaki, K., Nomoto, S., Yokota, Y. and Murai, T.: The effects of temperature, light, and sound on perceived work environment. ASHRAE Trans., 104(1A): pp.711-720,1998

38）兼子朋也，堀越哲美：尺度付言語選択法による温熱環境の心理的評価一 その 2 温冷感についての評定尺度法との比較・検討一, 日本建築学会大 会学術講演梗概集 D-1 環境工学 I, pp.843-844, 2000. 9

39）兼子朋也，堀越哲美：尺度付言語選択法を用いた日本人の温熱環境に対 する心理的評価に関する研究 その 2 単一評価・重複評定による冬季実験, 日本建築学会計画系論文集，553 号，pp.99-105，2002.3

40) 西應浩司, 松原斎樹, 合掌顕, 蔵澄美仁, 材野博司: 都市景観評価に対 する複合環境評価的視点からの実験的検討，日本建築学会計画系論文集， 522 号, pp.107-113, 1999.8

（2011年 1 月10日原稿受理，2011年 7 月15日採用決定） 